\title{
Post-disaster reorganisation of local and national institutions: the case of St. Martin after hurricane Irma (West Indies)
}

\author{
Gwenaël Jouannic ${ }^{1,2, a}$, Chloé Tran Duc Minh ${ }^{1}$ and Denis Crozier ${ }^{1}$ \\ ${ }^{1}$ Cerema Ouest, 9 rue René Viviani, 44220 Nantes, France \\ ${ }^{2}$ Cerema, EPR ESPRIM, France
}

\begin{abstract}
With the concept of "build back better", the United Nations emphasizes the importance of the recovery phase following a natural hazard as an opportunity to implement vulnerability reduction measures. This work here focuses on the ongoing recovery of the French part of island of St. Martin following hurricanes Irma in September 2017. The recovery of this semi-autonomous territory is a major challenge for the local authorities and for the French State. The current state of post-disaster recovery shows the difficulties of reconciling the two imperatives of "rebuild faster" and "rebuild better", in a context of social, political and media pressure. Therefore, what conditions would be necessary to take advantage of this key moment and make the small island more resilient to a new event? What do we learn from this experience for the management of the recovery?
\end{abstract}

\section{Introduction}

This work focuses on the post-disaster recovery phase of the island of St. Martin following Hurricanes Irma on $5^{\text {th }}$ September 2017, classified as category 5 on the SaffirSimpson scale (Cangialosi et al., 2018). The insured damage estimation to buildings, carried out by the French insurance federation, amounts to 1.176 billion euros for the French part of St. Martin (Gustin, 2018). The European emergency service provide a global damage assessment on buildings of St. Martin based on the analysis of satellite images. The results of this study estimate that Hurricane Irma create many damages with 5874 negligible damages (46.5\% of buildings), 2940 moderate damages ( $23.3 \%$ of buildings), 1323 severe damage (10.5\% of buildings) and 2486 destroyed damages (19.7\% of buildings) (Copernicus EMS Risk and Recovery data). In response to this exceptional situation, the French government aims to promote an exemplary reconstruction that draws lessons from the recent disaster and integrates the future consequences of climate change. A French government official report "a unique opportunity to rethink these territories differently [...]" (Gustin, 2017).

The aim of this study is to better understand postdisaster recovery management strategies in order to promote an early return to normal and a more sustainable and resilient redevelopment of the affected area. Through interviews, we identified the individual and collective experiences of the stakeholders who deal with and live through the everyday the recovery effort: local representatives, technicians from local authorities, state officials, companies, residents. In particular, this work

\footnotetext{
${ }^{a}$ Corresponding author: gwenael.jouannic@,cerema.fr

DOI 10.3311/FLOODRisk2020.19.8
}

questions the place of the French State services in the organization and management of the recovery of a disaster-stricken area.

\section{Methods}

Our approach is based on 3 methods: stakeholder interviews, press review and analysis of official reports. On one hand about 20 semi-directive interviews of St. Martin and St. Barthélemy local representatives, local and national French authorities have been realised during a mission in April 2019. Faced with the extent of the damage and the specific problems of post-disaster recovery, we felt the need to wait 18 months after Irma before starting the first mission. This delay allowed the actors interviewed to stand back on their reorganisation and the management of the reconstruction. On other hand, we recovered 80 documents from local and national authorities who participated or supported the recovery of the island. These documents widely deal with the subject of recovery on its regulatory, political, administrative and technical issues. A press review started in September 2017 and collecting about 250 articles from local and national newspapers completes this database.

\section{St. Martin, vulnerable territory}

\subsection{Administrative status of the island}

The island of St. Martin has been divided in 2 parts since 1648: a Dutch part called St. Maarten, and a French 
part called St. Martin (Fig. 1). The French part covers 53 $\mathrm{km}^{2}$ with 35700 inhabitants in 2016 (INSEE, 2016), the Dutch part has about 37000 inhabitants per $37 \mathrm{~km}^{2}$ (Servans, 2016). The French part is characterized by very strong recent demographic growth, from 8072 inhabitants in 1982 to 28518 inhabitants in 1990 (Servans et al., 2016; Nicolas, 2005). This is in relation to migration episodes notably associated with the influx of labour in the construction sector following the Pons tax exemption law in 1986 (Duvat, 2008; Redon, 2007).

The islanders readily assert that they firstly feel St. Martinois before being French or Dutch. However, the regulatory difference, which apply on either side of the porous border, have generated different economic and social models, creating a form of competition. For example, European law applies only on the French side, which has important consequences in terms of the standards of imported products, labour law and environmental law, while casinos and hostess bars are possible in St. Maarten which drains a lucrative tourist economy. The discourse of local actors is that families live on both sides, benefiting from the jobs of St. Maarten and the social rights of St. Martin.

In 2007, St. Martin changed its status from a municipality attached to Guadeloupe to an relative autonomous French overseas region (article 74 of the 1958 French Constitution). This change confers on it a specific status laid down by an organic law. The local authorities of St. Martin now exercise all the powers devolved to the three strata of local authorities (taxation, road transport, seaports, roads, tourism, state law, etc.) (JORF, 2007). The St. Martin local authorities set out the rules applicable, in particular with regard to urban planning, construction and housing. However, the French State remains competent to lay down rules in several areas, including the organisation of justice, defence, public security and the environment (including natural hazards). Post-disaster management therefore requires coordination between the local authorities, which is responsible for changing the urban planning rules and issuing planning permission, and the French State, which is responsible for defining the new rules for natural hazard management and environmental protection.

However, St. Martin local authorities has few financial resources and its administrative services lack of organisation due to a low ratio of executives (St. Martin's activity report, 2015). Either taking on new responsibilities, including its own urban planning code, is a major challenge before or after autonomy, a few dozen people, around a sub-prefect, were supposed to carry out all State missions for the two islands of St. Martin and St. Barthélemy. Moreover, Guadeloupean French State services forget that certain competences are still within their remit, including the risk management (a French official interview). Some authors describe a situation of a "double insularity" with respect to the Metropolitan France (Redon, 2007; Dosières and Gibbs, 2014; Gustin, 2017).

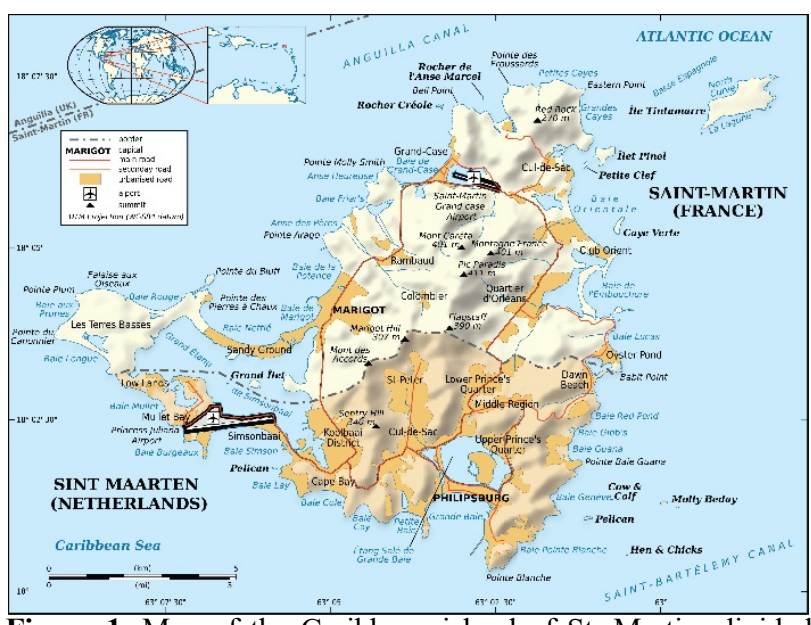

Figure 1. Map of the Caribbean island of St. Martin, divided between French and Dutch halves (adapted from Eric Gaba).

\subsection{A fragile socio-economic situation}

The GDP per capita of St. Martin is about $\$ 16600$ in 2010 , lower than France ( $\$ 42000$ in 2016). In comparison, St. Maarten have a GDP per capita of $\$ 22000$ (de Wit, 2015). Life expectancy on St. Martin is 76.3 years in 2015, lower than in mainland France (82.3 years in 2016). 25\% of the population has no social security cover (Redon, 2007), mainly due to undeclared work practices. These averages mask significant contrasts between very rich areas and humblest neighbourhoods. Moreover, some families of large landowners are very well established, and occupy strategic positions within the various decisionmaking bodies (Redon, 2007).

In $1990,61 \%$ of the population of the French part of St. Martin was foreign (Nicolas, 2005), mainly of Haitian nationality (Redon, 2007; Nicolas, 2005). The remaining $49 \%$ correspond to a metropolitan/European population and a minority population native to St. Martin (Magnan, 2008). 120 nationalities are represented in St. Martin (Redon, 2006) and French is only the fourth most spoken language. The officially recognized language is French, it is used for all the public services present on the island as a majority means of communication to exchange with the local population which partially mastering this language.

For the last 70 years, St. Martin has evolved from an agrarian economy (Monnier, 1981; Redon, 2006) to an economy based mainly on the hotel and residential tourism industry (Sanguin, 1982; Redon, 2006). To differ from St. Maarten, St. Martin puts a choice of quality tourism forward, with more preserved landscapes, more upscale restaurants, hotels and villas. However, inconsistently with this position, tax exemption policies led to massive investments in mass tourism accommodation in the mid1980s. St. Martin looks at the same time to the exclusive tourism model of St. Barthélemy, with a small but very wealthy clientele, and to the mass tourism model of the Dutch side, with a clientele attracted by duty-free and night activities.

The end of the tax exemption and the St. Martin ambiguous economic positioning has led to a slowdown in tourist activity. 14 hotels closed or were sold as apartments between 1995 and 2003 (Hyest et al., 2005). During 
interviews, St. Martin Chamber of Commerce and Industry also pointed out that the fragility of the tourism sector, which did not invest in new facilities, also led to the fragility of the construction sector (second largest economic sector). Beyond these social and economic fragilities, natural hazards are likely to affect the economy of a territory.

\subsection{Irma, a major event on a highly exposed territory}

Hurricanes are relatively common in the Caribbean and have regularly caused deaths and extensive damage in the northern Caribbean islands (Duvat, 2008). In one century, 17 hurricanes and 9 tropical storms have been recorded on these islands, an average of one event every 3.8 years (Duvat, 2008). For example, hurricane Luis in 1995 (category 4), with winds of around $200 \mathrm{~km} / \mathrm{h}$ in St. Martin (Cangialosi et al., 2018), damaged nearly 50\% of the hotel park and $80 \%$ of the dwellings on the French part of the island, while $30 \%$ of the dwellings were destroyed (Pagney Bénito-Espinal, 2006).

In 2017, Hurricane Irma killed 11 people and caused more than $€ 2$ billion in insured damage in the French islands of St. Martin and St. Barthélemy. Damages have been generated by the marine submersion (Fig. 2) or the wind. It seriously damaged coastal infrastructures and dwellings and triggered the mangrove partial destruction.

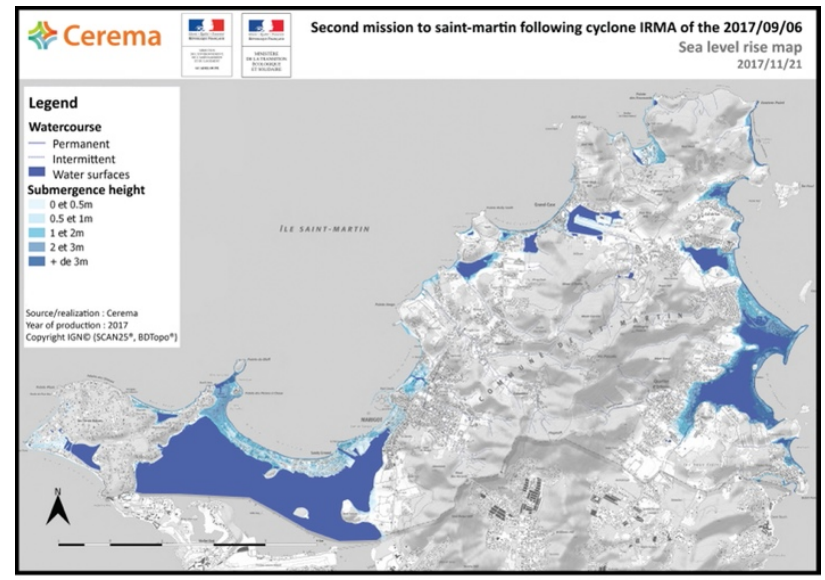

Figure 2. Map of flood heights based on the impacts of hurricane Irma on St. Martin (Source: Cerema).

Moreover, St. Martin is exposed to seismic hazards, floods and flash floods, landslides and soil liquefaction. The superimposition all of these natural hazards constraints limits the possibilities of construction on the island (Fig. 3).

In this highly exposed context, the impoverishment of the population and the very complex status of land ownership on the coast has encouraged the development of urbanisation, legal or illegal, not adapted to the risk. Moreover, St. Martin's population had very weak risk culture, which is predominantly populated by immigrants or French metropolitan.

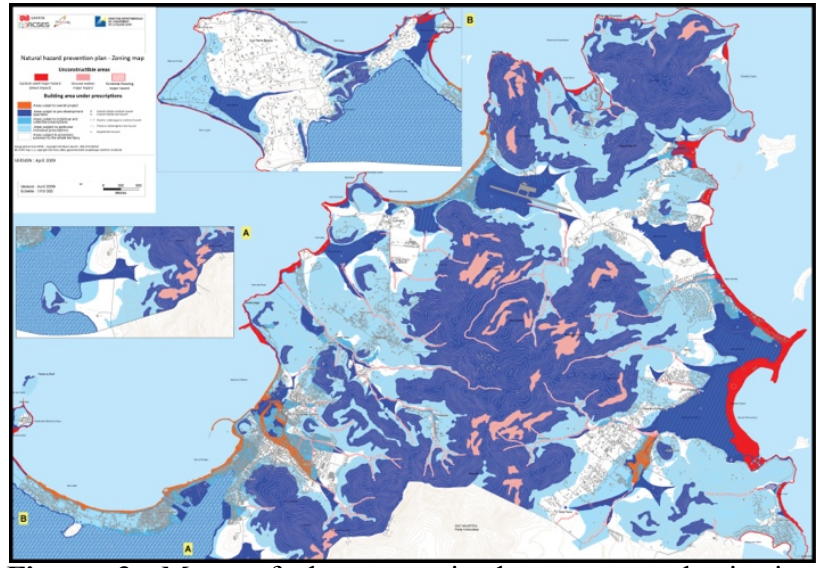

Figure 3. Maps of the constrained areas to urbanization according to the intensity of the natural hazards of St. Martin (Source: DDE Guadeloupe).

\section{A controversial toll of recovery}

In response to the catastrophic situation, both the French government and the local authorities of St. Martin have stated their ambition to build back better against natural hazards and to take into account other issues such as sustainable development. In an interview, the president of the local authorities of St. Martin, believes that "we do not rebuild, we build, the page is blank, we must use this opportunity to redesign the territory starting from scratch" (Le Monde, 2017). The prefect of St. Martin, Ms Laubies, suggests to rethink the development model of the 1970s and 1980s in St. Martin (Le Monde, 2017).

\subsection{Disputed reconstruction figures}

According to the report commissioned by the French Ministry on the damage assessment post-Irma on St. Martin (MTES, 2017), 95\% of the buildings have been impacted by Irma hurricane: $27 \%$ of residential buildings were irretrievably affected and/or have major structural disorders, $27 \%$ require roofing work, $20 \%$ require roofing and carpentry work. The monitoring of reconstruction is rapidly becoming subject of debate and controversy. The damage assessment is the subject of dispute between the reality perceived on the ground and the only official government assessment based on an interpretation of satellite images from the European space programme Copernicus, which, according to some, underestimate or overestimate the facts (Fig. 4). The local and national press (SoualigaPost, 2018; Le Figaro, 2018) also reports on the controversy over the relative reconstruction rate on the Dutch side compared with the French side. The quality of the reconstruction is also a matter of concern, as evidenced by the press release of the prefecture and the local authorities, which mentions many private individuals installing concrete slabs on their roofs (Fig. 5) without considering the structural risks in an area subject to seismic hazard (SoualigaPost, 2018). 


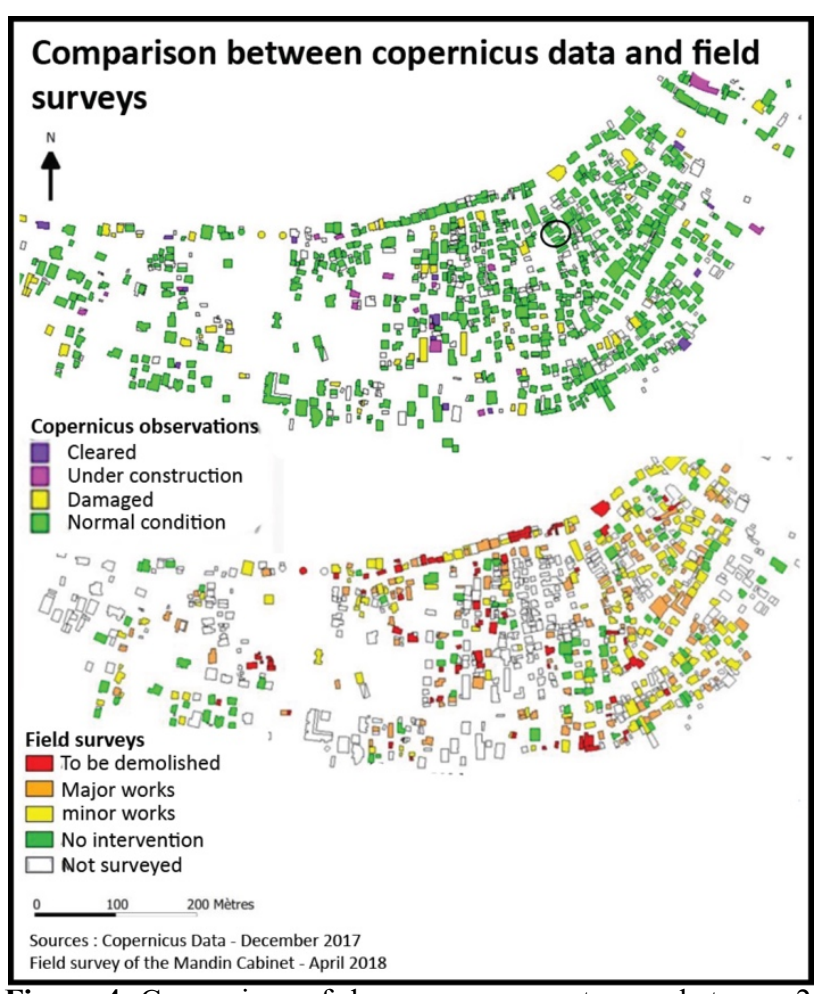

Figure 4. Comparison of damage assessment maps between 2 methods on the Sandy Ground neighbourhood. A) Assessment based on interpretation of satellite images (Source: Copernicus emergency management service). B) Assessment based on field visit and personal interview (Source: Madin'Etudes).

The reconstruction of the real estate assets of SEMSAMAR, the main social landlord in St. Martin, and of schools, which are perceived as slow, have been the subject of some of the most controversial debates. This was notably reflected in speeches by the French President denouncing the delays, accusing SEMSAMAR and the local authorities of inaction and threatening legal action (Le Monde, 2018).

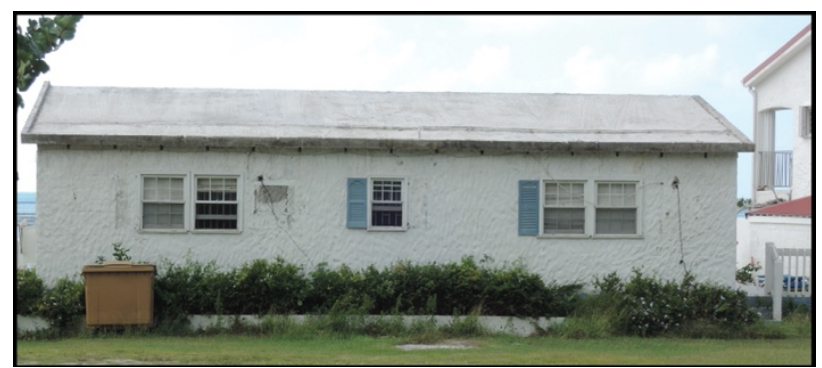

Figure 5. Concrete roof rebuilt after Hurricane Irma in Grand Case (Source: J. Gargani).

\subsection{Gradual recovery of tourism without upheaval}

The degraded image of St. Martin following hurricane Irma, coupled with the actual damage and closure of many hotels and restaurants, inevitably had a high impact economic. Nearly 9000 employees benefited from the partial activity scheme. The French State estimated the cost at between 46 and 75 million euros for the years 2017 and 2018 (Gustin, 2018).

However, as the tourism sector has been in difficulty for several years, the forced closure could be an opportunity to improve hotel infrastructure to make it more competitive and sustainable, as the president of the hotel association and director of the Beach Hotel pointed out in July 2018. Despite his optimism, he added that "all the tools exist, but everyone is moving forward in a scattered manner".

As of 1 July 2018, the St. Martin hotels association counted "150 rooms available out of the 14 member hotels, compared to 1163 before Irma" (SoualigaPost, 2018). The Dutch St. Maarten has economically started up again quicker, as it benefits from the transport infrastructures whose cargo deck. The operational cruise terminal made it possible to welcome tourists before the hotels reopened. This increased the willingness to "build back faster". Two and a half years later, 900 rooms were available, but the desired model by authorities after Irma had not changed. For example, the symbolic Secrets Resort and Spa reopens in 2020 without displaying any particular ambitions in terms of eco-tourism or more virtuous environmental ambitions.

For the President of hotel association, the present challenge therefore remains staff training (EWAG, 2019). However, according to Department of Enterprises and Employment (DIECCTE), these same restaurants and hotels have downgraded in order to attract a local clientele with lower prices. In order to meet this objective, they have also had to cut wages. Their employees often preferred to leave their jobs and work in the booming construction sector after Irma, looking for labour after the hurricane. The economic recovery will therefore not only depend on the number of rooms available.

\subsection{The environment}

Unlike St. Maarten, St. Martin is subject to European and French environmental laws. However, the landscape enhancement supported economically and legally by St. Martin benefits all tourists on the island (Dutch or French side). For example, tourists from St. Maarten organise tours on the French part of the island for their clients who wish to enjoy the protected sites of St. Martin. This protection of natural areas could help St. Martin to stand out and attract a clientele more concerned about environmental quality. On the contrary, the local authorities of St. Martin considers this difference to be an injustice compared to its more autonomous neighbour. The "compulsory" preservation of the landscape and coastline on the French side has been as a brake on the more lucrative development of a mass accommodation model.

The French institute of coastline protection reports recurrent conflicts. For example, after Irma, the Salines d'Orient pond has naturally been reconnected to the sea. The local authorities of St. Martin has initiated a procedure to close it, despite the ecological interest in letting nature take its course (testimony of coastline institute's director).

\subsection{The networks}

Networks are under great pressure following a major disaster to ensure the fastest possible restart of vital 
functions in the affected area (water, energy, telecommunications, transport, etc.).

Faced with the extent of the damage, the Orange company, in charge of managing the telecommunications infrastructure, quickly decided not to re-establish its overhead old copper network and replacing it with the installation of underground fibre optics throughout the French part of the island.

EDF company, which is responsible for the electricity network, also chooses to bury its network. The coordination of the construction sites of the electricity and telecommunications networks, and the financial distribution of the associated costs between the operators, the local authorities of St. Martin, and mainly the aid from the French State is the subject of many debates (Arnell et al., 2019; SoualigaPost, 2018). Finally, in April 2019, 70 $\mathrm{km}$ of networks were buried for electricity (less for telecommunications) for 18 million euros.

The French harbour and airport infrastructures of St. Martin have limited capacity to accommodate larger ships and aircrafts. During the crisis management, the aid and assistance sent by France therefore arrived via the harbour and airport of St. Maarten. This dependence on another country in a time of crisis led to putting projects envisaged before Irma back on the agenda for discussion: the opening of Grand Case airport to international flights (Hyest et al., 2005) or the increase in the draught of the commercial harbour of Galisbay (interview with the harbour manager). These two projects are part of a context of competition with infrastructures of the same nature but with much larger dimensions on the Dutch side. The project to extend the runway at the airport was finally cancelled because of the lack of project's profitability (SoualigaPost, 2019). The enlargement of the port to accommodate cruise ships in particular is under study.

\section{Recovery management, reorganisation of French State departments}

In this chapter, we will attempt to describe and analyse the evolution of French State departments in response to the French government's stated ambition to carry out exemplary recovery leading to a more resilient territory.

\subsection{Preparing for recovery in the immediate aftermath of the disaster}

Faced with the scale of damages and the feeling of having to build back everything from disaster, the ambition to carry out a more resilient recovery was at the heart of the reflections of the local authorities and the French government. 10 days after Hurricane Irma, the French Government created a new committee in charge of the post-disaster phase in order to support the recovery at St. Martin and St. Barthélemy and Prefect Gustin recently appointed "inter-ministerial delegate for the reconstruction of the islands of St. Martin and St. Barthélemy" accompanied the presidential delegation at St. Martin on September $14^{\text {th }}$. The creation of this kind of interministerial reconstruction unit was not the first (Crozier et al, 2016; Moatty, 2015; Prax, 2010). The appointment of a delegate strengthens this organization, which was done following hurricane Hugo on Guadeloupe in 1989, with the appointment of the Prefect of Guadeloupe (JORF, 1989) as inter-ministerial delegate for reconstruction. About post-Irma recovery, the Prefect Gustin appointment alongside Anne Laubiès, Deputy Prefect of Saint Martin, reinforces his mission (Fig. 6). It clearly identifies a "dedicated manager who has specific dedicated time and legitimacy to coordinate the different ministries", (testimony of prefect Gustin). Simultaneously, the Deputy prefect of Saint Martin can full-time focus with the urgency of crisis management. This organization is quiet similar to the one set up following the "Saguenay flood" in Canada in 1996, with the creation of an Office of Reconstruction and Economic Recovery attached to the Prime Minister (Jouannic et al., 2016). Reconstruction is thus a political objective clearly stated in speeches and actions the day after the disaster. Two months after Irma, the inter-ministerial delegate for the reconstruction presents the recovery strategy that the French government would like to pursue in St. Martin. Prefect Gustin aims to creating a post-disaster window of opportunity, despite the technical, social and political constraints (interview of territorial delegate for reconstruction).

At the $3^{\text {rd }}$ inter-ministerial committee meeting on 11 October 2017, it was noted that "one month after the disaster, the emergency phase appears to have been largely resolved". In addition to the inter-ministerial delegation for the reconstruction team composed of 6 people, civil servants from Guadeloupean Department of French Ministry of Environment (DEAL in French) and the government officials were temporarily removed from their services and assigned for two months to St. Martin, in order to support the recovery (testimony of DEAL's official).

At the same time, several teams of experts were dispatched on the spot as a matter of emergency, sometimes without coordination with all the actors involved locally. For example, the French Ministry of Environment commissioned two teams of floods experts, on September 2017 and at the beginning of October 2017, to model a new map of the cyclonic hazard by marine submersion. Simultaneously, the Council for Architecture, Town Planning and the Environment (CAUE) of Guadeloupe or the Geological and Mining Research Bureau (BRGM) have each one carried out damages assessments. The Scientific and Technical Building Centre (CSTB), which accompanied the French President on his first visit, is mobilised to assess construction standards. CSTB also had the task of bringing together local actors to develop a practical construction guide on post-hurricane repairs for the population of St. Martin (published on June 2018 in French, English and Creole). 


\section{Evolution of government services}

following Irma

simplified organisation

\section{Before Irma}

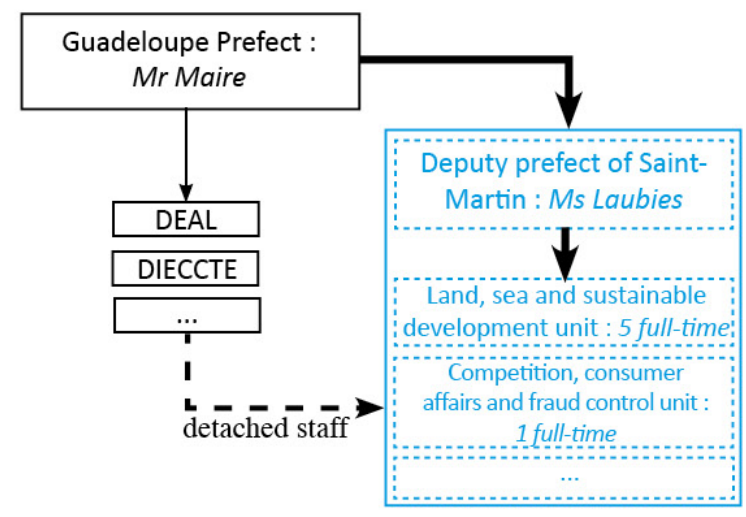

\section{Post-crisis}
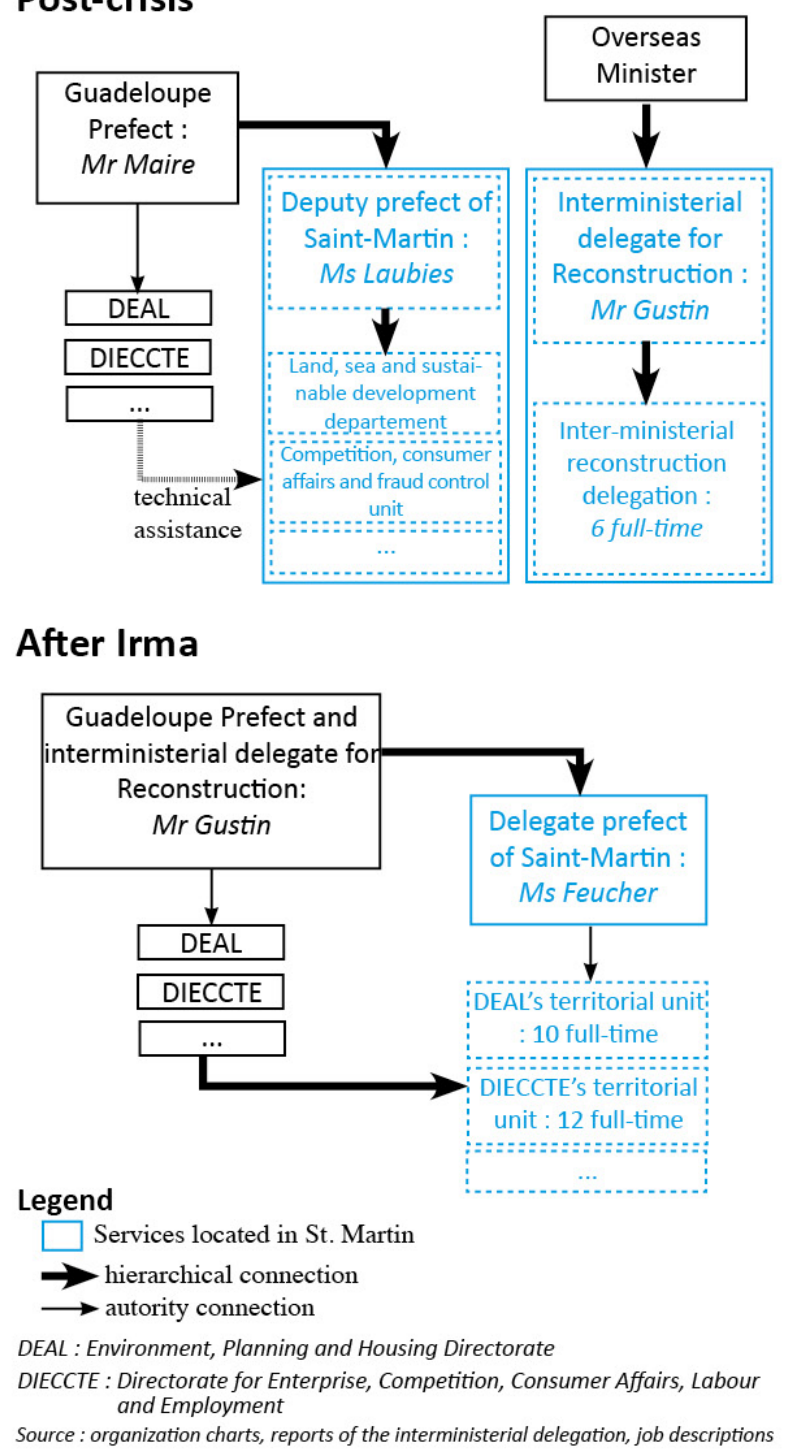

Figure 6. Scheme for the organisation of French State departments in Guadeloupe, St. Martin and St. Barthélemy, before Irma, during the post-crisis management and 2 years after Irma.

\subsection{An inter-ministerial delegation in direct dialogue between Paris and St. Martin}

The inter-ministerial delegation is the linchpin of the French State (see section 5.1) to support the recovery strategy on St. Martin and St. Barthélemy. It launches the initiatives or ensures the dialogue with the local authorities. This service, initially created for 3 months, was finally extended for a total of 15 months. Frédéric Mortier, territorial delegate for reconstruction to Prefect Gustin, emphasises that "Prefect Gustin's relations have made it possible to release significant sums from national and then European public funds to support the reconstruction". It should be pointed out that the interministerial delegation had neither an investment budget nor an operating budget. Prefect Gustin's first task required his presence mainly in Paris, in order to mobilise the various ministries and create a network of referents in the ministries and cabinets (interview of Prefect Gustin).

These difficulties in mobilizing all the ministerial departments whose involvement is needed in the postdisaster recovery emergency, but not a priority for them, has still been highlighted in previous disaster management (i.e. flash flood of the Saguenay region in Canada in 1996). In the case of Hurricane Irma, the Prefect Gustin devoted a significant part of his time to communicating on the action of the State (30 meetings in 2 months, interministerial commissions and about 100 press interviews).

For some local Guadeloupean Department of French Ministry of Environment (DEAL), the emergency appointment of inter-ministerial delegation resulted in a lack of information and consultation on its activities. A DEAL's task officer testimonies that the delegation's missions had never being explained to its departments. Some are even more negative, according to them the creation of the inter-ministerial delegation unfortunately generated tension, with the feeling that local experience and knowledge of the pre-hurricane context had not been mobilized.

The Madin'Etudes Cabinet, mandated to carry out a building damage assessment in spring 2018, underlines the difficulties of coordination between the different actors in the post-disaster period. Although this damage assessment mission has been initiated by the inter-ministerial delegation, the recruitment has been steered by the DEAL department in Guadeloupe without following the study afterwards. Monitoring has been carried out by a member of the delegation located in Paris. Madin'Etudes Cabinet's contacts with the delegation's representatives on St. Martin were limited. Although associated with the terms of reference, the local authorities of St. Martin seemed to discover the study on its first day. Finally, although the study has been presented as a first mission to assess needs for reconstruction aid, no coordination has been made with the other teams of experts already present on the island (CAUE, Compagnons Bâtisseurs, etc.).

Nevertheless, other interlocutors based in Guadeloupe often highlighted the major role of Prefect Gustin as a privileged interlocutor on the subject of reconstruction and economic recovery of the island.

The temporary creation of this inter-ministerial delegation for reconstruction may have had positive 
impact on several points: speed in decision-making (procedures for aid to businesses, procedure for obtaining a works permission after Irma, strengthening of the French State Department in St. Martin, etc.). A review of the actions of this specific State entity was published one year after Irma, this report explains in particular that: "A real bridge between the St. Martin local authorities and the Parisian officials, the delegation was able to make a quick assessment of the Northern Islands after the hurricane Irma and make recommendations for exemplary and sustainable recovery. The inter-ministerial work in Paris enabled a rapid and flexible response to the challenges, by adapting procedures and "inventing" ad hoc mechanisms (Gustin, 2018)". This report underlined the possible transposability of this specific organisation to other major crises.

However, it seems to have been partly to the detriment of the involvement of local services. Nowadays, national French officials did not use to work with St. Martin authorities. The neglect at the beginning of the crisis of the competent staff located in Guadeloupe and St. Martin unfortunately did not encourage the later investment of these local services during the recovery period.

\subsection{Towards a sustainable organisation of the French State on St. Martin}

The inter-ministerial delegate for the reconstruction of the islands of St. Martin and St. Barthélemy previously presented is temporary service (see section 5.1). A new sustainable organisation of the French on St. Martin has been established in June 2018 to gradually take over the missions of the inter-ministerial delegation in accordance with the protocol signed between the French Government and the local authorities of St. Martin the $17^{\text {th }}$ November 2017, two months after the hurricane, on the initiative of Prefect Gustin: "the State will ensure, in St. Martin, the permanent representation of several State departments currently located in Guadeloupe". A new Delegate Prefect for St-Martin and St-Barthélemy (Sylvie Feucher) was appointed on June 2018 replacing the previous sub-prefect. Several recruitments have been launched to create several territorial units to support the public action of the French government (Fig. 6). The prefecture building located at Marigot (St. Martin) was destroyed by Irma, as a consequence temporary workspaces have been built to accommodate these new State departments.

The Department of the Environment (including natural hazards), Urban Planning and Housing (DEAL) currently has officially 8 staff members on St. Martin, including 4 executives until the end of the recovery period. In order to anticipate the closure of the inter-ministerial delegate for the reconstruction, the people recruited in the new St. Martin service of the DEAL had to work closely with the inter-ministerial delegation to allow continuity in the actions already undertaken. The following extract from a job advertisement for the St. Martin DEAL unit testimony of this will: "The civil servant will work in coordination with the inter-ministerial delegation for reconstruction, [...]. Main activities: Monitoring the actions undertaken by the mission of the specific delegation for the reconstruction of St. Martin". However, during the interviews conducted with the members of the DEAL unit at St. Martin, they reported very few coordination meetings with the members of the interministerial delegation before its dissolution.

Moreover, the interviews that we had with several State representatives in Guadeloupe and St. Martin underline the lack of experience of the new hired managers 1) on the management of natural hazards, 2) on the specific context of the West Indies and finally 3 ) on administrative procedures of the French State. This lack of experience has required the establishment of an accompaniment of this new DEAL unit at St. Martin by more experienced DEAL headquarters departments located in Guadeloupe. Consequently, the Guadeloupean risk management unit spent $30 \%$ of its time on post-Irma management on St. Martin for a year and a half (account of executive officer of the DEAL Guadeloupe). This temporary work investment on St. Martin has postponed missions initially planned on the island of Guadeloupe, in particular the management of Hurricane Maria, which directly followed Irma and hit Guadeloupe. The creation of the St. Martin's DEAL unit, not previously planned, was taken in an already difficult context as a measure to relieve the DEAL headquarter of Guadeloupe, consequently the support from Guadeloupe quickly became more distant. In April 2019, an executive officer of the DEAL Guadeloupe stated "The French State has provided resources specifically dedicated to St. Martin, the territorial unit of St. Martin DEAL unit must quickly be autonomous".

During the field mission carried out in April 2018, after a few months of existence of the St. Martin's DEAL units, the new local State organization seems well sized for day-to-day management, but still insufficient for the specific period of recovery that is far from over (account of Delegate Prefect for St. Martin and St. Barthélemy). In particular, the delegated prefecture and the St. Martin's DEAL unit must rapidly carry out the complete revision of the urban planning rules according to the intensity of the natural hazards, and more specifically the impacts of Hurricane Irma.

During his visit the $29^{\text {th }}$ and $30^{\text {th }}$ September 2018, President Macron confided his will to "strengthen the territory's capacity to deal with natural hazards" and announced the revision of the Natural Hazards Prevention Plan (PPRN in French) and its approval "at the end of 2019". "The State will present the new maps that will take into account the combination of tsunamis, earthquakes and cyclones by the end of the year [2018]," he said. The decree stipulating the revision of the PPRN in its cyclonicmarine submersion section was issued in March 2019 and the decree prescribing its early application on 6 August. The public inquiry is scheduled to take place in October 2019 and the final adoption of the PPRN is scheduled for December 2019. The French government therefore undertook to modify the urban planning rules within one year. As a general rule, the preparation of such a plan requires 2 to 3 years, or even longer depending on the local context.

\subsection{Recentralisation of State actions by Paris}


The elaboration of the Natural Hazards Prevention Plan is one of the State's flagship actions for a more resilient recovery of the island, with the burying of the networks mentioned above. However, it is one of the most socially and politically sensitive issues, since in the most exposed areas, it may be prohibited to rebuild homes damaged by the hurricane. Land available outside the natural hazard area is scarce on the island, as shown on the multi-hazards zoning map (Fig. 3). Displacement of the people affected would also pose great difficulties (Hino et al., 2017, Jamero et al., 2017). Moreover, the areas the most impacted by hurricane Irma are either the sectors that host tourist infrastructures (hotels, restaurants, beach club, etc.) or the poorest populations on the island (Quartier d'Orléans, Sandy-Ground, etc.).

In fact, consultation with local elected officials and socio-economic actors of St. Martin, which is a regulatory obligation, was strongly disrupted. Three public meetings have been initially planned by the prefecture. The first one was relatively short with low participation (SoualigaPost, 2019). The second meeting, which brought together many more people, was more chaotic, the room was so crowded that not everyone could get in (SoualigaPost, 2019). People protested against the lack of simultaneous translation into English, the most widely spoken language on the island, then after 15 minutes the meeting has been suspended. Faced with this situation, the prefecture broadcasts a presentation by the prefect on Facebook to present the new Natural Hazards Prevention Plan, subtitled in English (Facebook video here). A third public meeting is finally held on 29 May 2019, which lasted only a few minutes before be cancelled too (SoualigaPost, 2019).

While the situation is complicated for the State services on St. Martin with the population, it is also a source of tension with the local authorities, despite technical meetings and presentations to elected officials. On several times, elected officials express their fears about the impacts of the PPRN on the island's tourism development capacities (SoualigaPost, 2019). The president of St. Martin, Mr Gibbs, multiplies the criticisms, and organises a march through the streets personalities of the island (SoualigaPost, 2019) and wishes to organize his own alternative consultation (letter from President Gibbs to the Minister for Overseas France in August 2019). In particular, he criticized the flood hazard map and questioned the measurements taken following Irma hurricane. He invites the inhabitants to contribute again to the measurements (SoualigaPost, 2019). In return, the prefecture denounces the lack of timely reaction from the local authorities during the consultation of associated public persons. The results of the consultation process show repeated requests from the State services to obtain a map of the future projects.

The revision of the Natural Hazards Prevention Plan becomes the subject of crystallisation of all the tensions and fears that the inhabitants express as to the future of their property, and beyond that, for their future. The local authorities of St. Martin reproaches the State for putting a halt to tourism development on the island, while some inhabitants, often among the poorest, reproach the State for favouring the richest by authorising, under certain conditions, the construction or rebuild of hotels close to the shore (Le Monde, 2019; SoualigaPost, 2019).

Following the favourable opinion of the public inquiry commission to accept the new Natural Hazards Prevention Plan without major modifications, riots broke out in December 2019 (Liberation, 2019). After several days of rioting, the Minister for Overseas France announced an audio message on radio that "the PPRN will be corrected" and that an inspection mission led by Dominique Lacroix, former Deputy Prefect of Saint Martin from 2007 to 2009, would be sent in January (Le Figaro, 2019). In response, President Gibbs calls for the outright suspension of the Natural Hazards Prevention Plan. Two days later, the minister announced on the same channel the suspension of this plan in its current state and its early application for a period of three months (Soualigapost, 2019).

This last episode of post-disaster management by the State department, which saw the French Government directly disavowing confidence in its local services on St. Martin, illustrates the fragilities and pre-existing tensions in Irma, which constitute the foundations of the vulnerability of the island. On the one hand, there are the conflictual relations between the local authorities of St. Martin and the St. Martin State Department, which result in particular from the maladministration of St. Martin by French State services for years. On the other hand, there are social tensions resulting from the high level of inequality in such a small area (Redon, 2006). These tensions crystallise in particular on the coastal area, which concentrates the main natural hazards, the main tourist investments encourage by the local authorities, and the most fragile populations (e.g. Sandy Ground) which have no alternative solution.

\section{Discussion}

The analysis of these interviews and documents highlights the obstacles and factors facilitating the emergence of a territorial recovery strategy. Hurricane Irma revealed existing vulnerabilities and tensions related to the ultramarine or specific context of St. Martin. Beyond these initial vulnerabilities, we identified 6 points that exacerbated the vulnerability of the island of St. Martin during the post-Irma recovery.

\subsection{The lack of knowledge of St. Martin before Irma for the French Departments State}

The strengthening of the French State in St. Martin following Irma responds to a need to accompany the recovery of the island following the hurricane.

Nevertheless, the French State became aware of the existence of St. Martin at the occasion of Irma. This is true for the metropolitan services, but also, to some extent, for regional services based in Guadeloupe Island. Ministry of the Environment employees, assigned to the risk management department positioned in Guadeloupe testified that they rediscovered the existence of St. Martin after hurricane Irma (although this island is part of their area of competence). In addition, most of the French State employees assigned after Irma to these new services, 
including the new delegate prefect, have no knowledge of the island of St. Martin, of the local specificities of its organisation. As a result, they do not know the baseline state of St. Martin before Irma. This situation results in misunderstandings on the question of the "return to normal" of St. Martin which is not shared between the inhabitants present before Irma and the people who arrived to help after Irma. Thus, State representatives and experts sent after Irma (mainly from Metropolitan France), often have a distorted image of the island and imagine a zero state towards which they would like to move St. Martin, which is far from the reality of this island before Irma (Fig. 7).

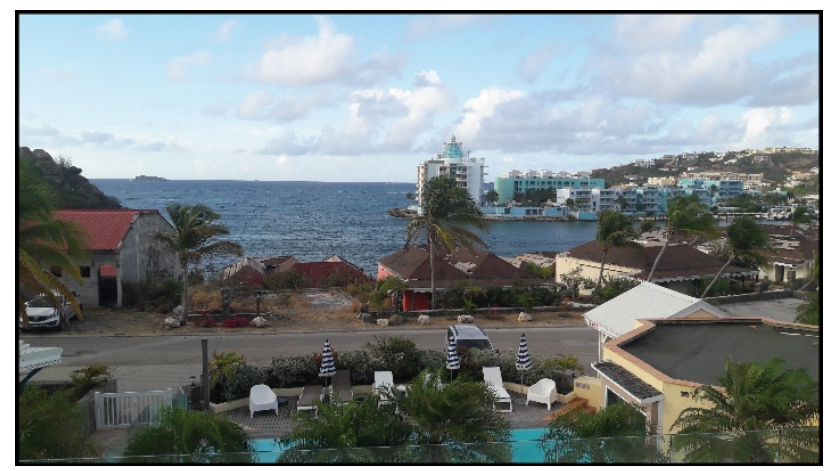

Figure 7. Example of unfinished building (building with the red sheet metal roof on the left side of the picture) dating from several years before Irma (Source: the authors).

In this sense, on the progress of the post-Irma waste clean-up, many government officials felt that the clean-up was progressing too slowly 18 months after Irma (Fig 8). Conversely, some residents of St. Martin were proud to testify to the significant efforts made to collect this waste and to have a cleaner island 18 months after Irma than before the hurricane.

\subsection{A complex interplay between local stakeholders}

The crisis generated by hurricane Irma has forced many political and socio-economic actors to work together in an emergency. For example, the rules for access to short-time working have been simplified and extended to support businesses on St. Martin. A single fund has been dedicated to facilitating the process of short-time working. Nevertheless, the start was difficult for St. Martin, as the scheme required proof of being up to date with its tax obligations. St. Martin companies, on the one hand having lost a lot of paper documents with the hurricane, and on the other hand not always in order with the tax authorities, were at first very suspicious of this request for transparency from the State in this difficult period (interview of Department of Enterprises and Employment). In addition, the single fund did not work well, as the various administrations concerned did not have the same procedures and working habits.

A technician from the territorial authorities of St. Martin believes that despite promises, the State services have not shown sufficient flexibility in administrative procedures in times of reconstruction. The newly introduced controls after Irma add administrative burdens on departments and companies that are not used to these procedures. Dissension persists even at the highest levels. In order to clarify the role of each party in this new organisation, a protocol has been signed in November 2017 between de the French State and the local authorities of St. Martin. This protocol states that "in return for the exceptional support of the French State, which is essential for the sustainable restoration and financial equilibrium of the territorial authorities of St. Martin, the latter undertakes to continue its proactive approach to improving (1) tax revenue and (2) the management of its internal departments and human resources". One year after Irma, French President Macron said, "We are going to put pressure on the local authorities of St. Martin to get the reconstruction works planning done. [...] St. Martin is an island where there has been too much collusion, too many arrangements, sometimes even corruption and that has to stop. [...] More controls will be put in place because I cannot accept what I have seen today".

All these factors contribute to fuelling prejudice and mistrust between the local authorities of St. Martin, the representatives of the French State in Guadeloupe and Metropolitan France, and the socio-economic actors. This respective lack of trust plays a major role in slowing down reconstruction projects.
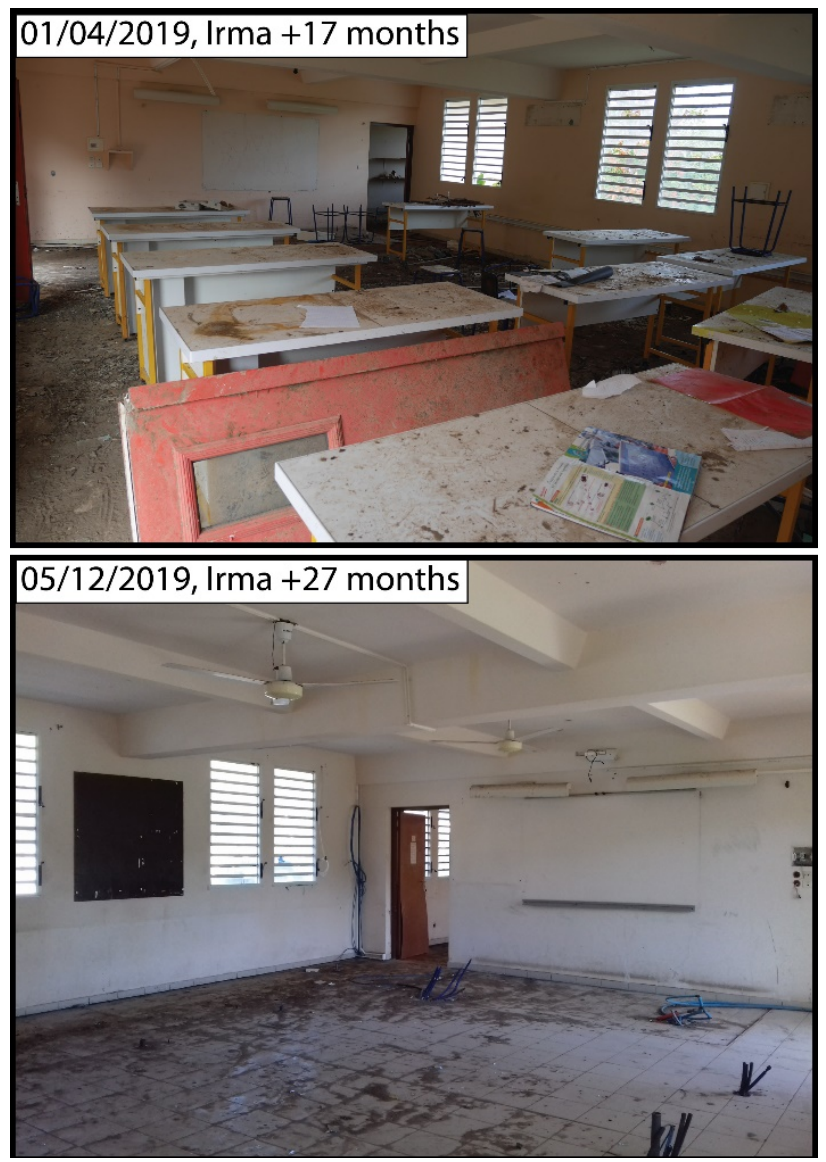

Figure 8. Evolution of the cleaning of Souliga school at 17 months and 27 months after hurricane Irma (Source: the authors). 


\subsection{Failure to take into account local expectations}

Previous works based on the analysis of post-disaster case studies have shown that the recovery phase following natural hazards is not the most favourable period to elaborate a more resilient territorial reconstruction project and unfortunately plays in favour of an identical reconstruction (Comerio, 1998; As Alesch et al., 2008; Olshansky and Chang, 2009). Our work shows once again that the island of St. Martin is still facing multiple difficulties to build back better after Irma in order not to reproduce past errors. The fear of the population of St. Martin is to be expropriated from their homes close to the coast and to be forced to live in an area less exposed to marine submersion. The lack of transparency and consultation with the population on the elaboration of reconstruction rules has fuelled a climate of mistrust of the inhabitants towards the French State as well as the local authorities of St. Martin which encounters many difficulties to exchange serenely with the population (Jouannic et al., 2020).

Despite several attempts by the French State to present to the population the new rules for urbanization in areas subject to the coastal flooding ( 2 public meetings have been cancelled in May-June 2019 due to the strong tensions during the presentations), the necessary trust of the inhabitants during this prolonged crisis period could never be established with the local authorities. The situation led to a social crisis in December 2019, with the blocking of roads to stop traffic on the island, in order to obtain the withdrawal of the Natural Hazards Prevention Plan.

Conflict situations between decision-makers and the population are regularly observed during the post-disaster recovery phase. Several studies describe and analyse the difficulties faced by the cities of Chicoutimi in Canada (Saguenay Flood in 1996) and New Orleans (hurricane Katrina in 2005) which tried to carry out projects to rebuild differently after these disasters. In both cases, the lack of involvement of the citizens to take into account their wishes in the elaboration of these redevelopment projects led to their abandonment (Campanella, 2006; Crozier et al., 2016).

The success of the long-term management of post-disaster recovery requires the identification of a leadership that will elaborate a reconstruction project shared by all the actors. On the one hand, this territorial leader must be able to make quick decisions in this period of emergency and on the other hand know how to listen to the expectations of the population (Maret and Cadoul, 2008). In the case of St. Martin, no actor currently seems legitimate for the population to support its expectations in the recovery of the island.

\subsection{The lack of experienced human resources and skills}

As previously explained, the French State had progressively abandoned the management of St. Martin following its autonomy obtained in 2007.
On one hand, following Hurricane Irma, the State decided to massively reinforce its presence on St. Martin with, in particular, the creation of a temporary structure to support short-term recovery (Inter-ministerial reconstruction delegation) and a permanent local unit in charge of development and risks (Fig. 6). Nevertheless, most of the staff assigned to this new department in charge of urban planning and risks management are temporary staffs and have very little experience in the field. The modification of the urban planning rules taking into account hurricane Irma (constrain areas to urbanization according to the intensity of the natural hazards) would have been facilitated with the permanent support of experts, above all in the post-Irma highly conflictual context.

On the other hand, despite a large workforce (around 1300 agents), the local authorities of St. Martin lack managers and engineers to monitor and support the vast recovery of the island (Gustin, 2018). The need for leading and management of the many departments of this autonomous local authority therefore remains important to carry out an unprepared and cross-sectoral reconstruction project (testimony of an executive from the local authorities of St. Martin). The risk management of the local authorities has only two officers, who focus only on crisis management and fire regulation.

\subsection{Conflicting objectives within unsustainable deadlines for recovery}

In view of the extent of the damage generated by Irma, the French State has decided to modify as quickly as possible the urban planning rules on St. Martin in areas exposed to natural hazards. In light of the extent of the damage, the government wished to act quickly (see Section 5.3) and asked local French State departments to update the Natural Hazards Prevention Plan by the end of 2018 (Gustin, 2018). This very short deadline did not allow the local authorities to organize the necessary consultation with local elected officials and socio-economic actors, and the mandatory presentation of the new rules to the populations resulted in a document deemed very unsatisfactory by the local authorities of St. Martin and the population. Following the social outcry in December 2019, the French Minister for Overseas finally temporarily cancelled the application of these rules to allow extension time for discussions with local officials and socioeconomic actors.

In 2018 (one year after Hurricane Irma), the local authorities of St. Martin did not choose to concentrate their actions solely on the reconstruction of their territory, but preferred to focus both on the post-disaster recovery of the island and to maintain in parallel the projects originally planned in the 2018 budget (testimony of an executive from local authorities of St. Martin). Indeed, in April 2018, St. Martin Gibbs' president, presented "a budget for recovery and responsibility", adding that "if the recovery of the territory represents an important part of the expenditure, the original budget also provides for the financing of new operations such as studies for the development of the Quartier d'Orléans and Sandy Ground, 
the landscaping of Marigot or a temporary development of the beachfront restaurants". The lack of clear organization of their technical departments and the low number of managers and engineers were major obstacles in helping the local authorities of St. Martin manage the post-disaster phase (account of technicians from the State and the local authorities of St. Martin). It would have been preferable in the 12 months following Irma to concentrate efforts solely on the recovery of the territory.

\subsection{A constraining method of financing recovery}

One year after the hurricane Irma, the French Government allocated 493 million euros to St. Martin and St. Barthélemy, one third of which was for emergency measures and two thirds for support for the economy and long-term recovery (Gustin, 2018).

The State quickly ruled out the creation of a single fund dedicated to recovery and chosen to release credits gradually, according to concrete projects targeted at the real expectations of the territory. This individualized project-by-project financing has been preferred to ensure real control over the use of funds. This desire not to create a single fund dedicated to recovery (as the Dutch government did with St. Maarten), but to work with individualised funding on a project-by-project basis responds to a lack of trust on the part of the French State in a local authorities that is considered to be failing (problem of misappropriation of public funds, corruption, etc.).

About the St. Martin local authorities, they structurally lack executives, managers and an organisation to ensure the processing of files related to the reconstruction and respect the very short deadlines imposed by the French State. The State's system of financing recovery is time consuming and requires significant human resources which the St. Martin local authorities does not have. Consequently, the St. Martin local authorities was in difficulty due to the administrative burden of financing the recovery. The method of financing the reconstruction was here a major factor in slowing down the island's recovery.

\section{Conclusion}

The ambition to build back better after a disaster was high because of the lack of an example in Metropolitan France of a large-scale recovery project after a disaster. Is St. Martin less vulnerable today? This is not obvious, as the tension over the new risk management rules shows. It must nevertheless be underlined that the burying of electricity and digital networks is a significant step forward. Such a disaster should have led to profound changes, but Luis' scenario seems to be repeating itself (Duvat, 2008; Veyret, 2017).

For some local officers of the Ministry of the Environment, the feedback from the recovery of St. Martin is too specific to provide useful lessons for other territories. However, analyses of this work highlighted several issues about the post-disaster recovery, which have over the social, economic and political specificities of the context of St. Martin.

The controversies over the different perceptions of the effectiveness of the rehabilitation, reconstruction works and recovery underline the importance, beyond the damage assessment, of knowing the initial situation before the hurricane, especially when, as here, the officers mobilised after the disaster were not familiar with the local context. This recommendation had already been underlined after hurricane Lenny in 1999 (MEDD, 2003).

The failure of the original ambition to promote a new economic and social model underlines here, that the recovery phase is not an opportunity to transform a territory due to the strong collective will to return to the initial state. As previously observed in a naturally conflictual context (de Vanssay, 2010; Jouannic et al., 2016), recovery actions must remain strictly linked to risk management in order to be accepted by the population.

However, this acceptance is not automatic. In this sense, the new measures of the Natural Hazards Prevention Plan are subjected to massive rejection by the population. The long uncertainty about the new applicable urban planning and construction rules, the feeling of inequality in the measures and the fact that not all the alternative projects envisaged could be realised (e.g. relocation or dyke buildings), did not help to win acceptance. Experience shows that in times of doubt, solutions and elements of stability should be presented at the same time than the new hazards maps (MEDD, 2003; Crozier et al., 2016).

An exemplary approach to recovery requires excellent coordination between all local actors and external support (Berke et al., 1993). Nevertheless, in the case of St. Martin post-Irma recovery, the plethora of major actions to reorganize local services, carried out at the same time as the post-Irma recovery (reorganisation of the French State services on St. Martin, political management choices of the St. Martin local authorities) contributed to a lack of visibility of the specific role of all parties involved in the recovery. In particular, the inability to organize collegial management of the construction, through a team mixing the main stakeholders of St. Martin involved in the recovery of the island, has hindered the identification of the necessary leadership (Maret and Cadoul, 2008).

Finally, the choice not to rely on a single dedicated fund made the financing of the recovery more complex. While this choice was a response of French Government to the risk of public embezzlement, we observed that unfortunately the St. Martin local authorities had limited financial engineering capacities against a strong increased need. A clear understanding of the conditions for mobilizing financial resources dedicated to recovery is clearly a condition for post-disaster recovery success (Berke et al., 1993), which require a strengthening of the local technical resources.

To conclude, the management of the St. Martin recovery underlines once again the relevance of planning this phase similarly to the existing anticipation and preparation for crisis management (Berke et al., 1993; Crozier et al, 2016; Moatty, 2015). 


\section{Acknowledgments}

This study has been supported by the Relev project and funded by the Agence Nationale de la Recherche (ANR18-OURA-0004). All the people who agreed to give time to the authors to testify about their field experience are gratefully acknowledged. The authors would like to thank the European Copernicus programme "Risk and Recovery Mapping", as well as the CNES for the provision of geographical and satellite data.

\section{References}

1. Alesch, D.J., L.A. Arendt and J.N. Holly (2008). Managing for long-term community recovery in the aftermath of disaster. Public Entity Risk Institute, p. 205.

2. Arnell, G., A. Hassani and J.F. Rapin (2019). Les risques naturels majeurs dans les outre-mer (volet relatif à la reconstruction et à la résilience des territoires et des populations. Rapport d'information $n^{\circ} 122$ (2019-2020) fait au nom de la délégation sénatoriale aux outre-mer, p. 240.

3. Berke P.R., Kartez J., Wenger D. (1993). Recovery after disaster: achieving sustainable development, mitigation and equity. Disasters, 17(2), 93-109.

4. Campanella, T. (2006). Urban Resilience and the Recovery of New Orleans. Journal of the American Planning Association, 72, 141-146.

5. Cangialosi, J.P., A.S. Latto and R. Berg (2018). Hurricane Irma (AL112017). National Hurricane Center Tropical Cyclone Report, p. 111.

6. Comerio, M.C. (1998). Disaster hits home: new policy for urban housing recovery. Berkeley, University of California Press, p. 326.

7. Crozier, D., G. Jouannic, C. Tran Duc Minh, Z. Kolli, E. Matagne and S. Arbizzi (2017). Reconstruire un territoire moins vulnérable après une inondation : une fenêtre d'opportunité encore difficilement mobilisable. Espace populations sociétés, 2016/3, p. 20.

8. de Vanssay B. (2010). La reconstruction développement durable et réduction de la vulnérabilité. Institut des Risques Majeurs, Risques Info, 24, 6-8.

9. De Wit, O.W. (2015). St. Maarten National integrity system assessment 2015. Transparency International, p. 145 .

10. Dosières, R. and D. Gibbs (2014). Travaux d'une mission d'information sur la collectivité d'outre-mer de Saint-Martin. Rapport d'information $\mathbf{n}^{\circ} \mathbf{2 1 2 8}$, Assemblée Nationale, p. 174.

11. Duvat, V. (2008). Le système du risque à Saint-Martin (Petites Antilles françaises). Développement durable et territoires, 11, p. 23.

12. Gustin, P. (2017). Repenser les Iles du Nord pour une reconstruction durable. Délégation interministérielle à la reconstruction des îles de Saint-Barthélemy et Saint-Martin, p. 34.

13. Gustin, P. (2018). Les îles de Saint-Martin et de SaintBarthélemy, un an après IRMA - Bilan d'une année d'action de l'Etat dans la reconstruction des îles du Nord. Délégation interministérielle à la reconstruction des îles de Saint-Barthélemy et SaintMartin, p. 33.

14. Hino, M., C.B. Field and K.J. Mach (2017). Managed retreat as a response to natural hazard risk. Nature Climate Change, 7, 364-370.

15. Hyest J.-J., C. Cointat and S. Sutour (2005). L'avenir statutaire de Saint-Barthélemy et Saint-Martin : le choix de la responsabilité. Rapport du Sénat, 329, p. 89.

16. Jamero, M.L., M. Onuki, M. Esteban, X.K. BillonesSensano, N. Tan, A. Nellas, H. Takagi, N.D. Thao and V.P. Valenzuela (2017). Small-island communities in the Philippines prefer local measures to relocation in response to sea-level rise. Nature Climate Change, 7 , 581-586.

17. JORF, 1989. Décret $n^{\circ} 89-830$ portant création du comité interministériel pour la reconstruction de la Guadeloupe. Journal officiel de la République française, p. 14088.

18. JORF, 2007. Loi organique $\mathrm{n}^{\circ} 2007-224$ du 21 février 2007 portant dispositions statutaires et institutionnelles relatives à l'outre-mer. Journal officiel de la République française, p. 3220.

19. Jouannic, G., D. Crozier, C. Tran Duc Minh, Z. Kolli, F. Arki, E. Matagne, S. Arbizzi and 1. Bomperin (2016). Post-disaster recovery: how to encourage the emergency of economic and social dynamics to improve resilience? Proceedings of the $3^{\text {rd }}$ European Conference on Flood Risk Management, E3S Web Conf., 7, 17004, p. 9.

20. Jouannic, G., A., Ameline, K., Pasquon, O., Navarro, C., Tran Duc Minh, A.H., Boudoukha, M.A., Corbillé, D., Crozier, G., Fleury-Bahi, J., Gargani, P. ,Guéro (2020). Recovery of the Island of Saint Martin after Hurricane Irma: An Interdisciplinary Perspective. Sustainability, 12, 8585.

21. Magnan, A. (2008). L'espace littoral a-t-il toujours de la valeur? Réflexion à partir du cas de l'île de SaintMartin (Petites Antilles). Norois, 206, 37-52.

22. Maret, I. and T. Cadoul (2008). Résilience et reconstruction durable : que nous apprend La Nouvelle-Orléans ? Annales de Géographie, 663, 104-124.

23. MEDD (2003). Retour d'expérience sur la prise de décision et le jeu d'acteurs : le cas du cyclone Lenny dans les Petites Antilles au regard du passé. Technical Report, Ministère de l'Ecologie et du Développement Durable, p. 333.

24. Ministère de la transition écologique et solidaire (2017). Mission d'évaluation des dommages à SaintMartin, post cyclone Irma. Rapport de la Direction Générale de l'Aménagement, du Logement et de la Nature, p. 39.

25. Moatty, A. (2015). Pour une Géographie des Reconstructions post-catastrophe : Risques, Sociétés et Territoires. Thèse de doctorat. Université PaulValéry Montpellier III. Montpellier, p.489.

26. Monnier, Y. (1981). L'immuable et le changeant : étude de la partie française de Saint-Martin. CRETCEGET, collection « Illes et archipels », p. 125. 
27. Nicolas, T. (2005). Le fragile équilibre d'une îlecarrefour: Saint-Martin. In N. Bernardie and F. Taglioni (dirs.), Les dynamiques contemporaines des îles-relais: de l'île escale aux réseaux insulaires, Karthala, Hommes et société, pp. 163-180.

28. Olshansky, R. and S. Chang (2009). Planning for Disaster Recovery: Emerging Research Needs and Challenges. Progress in Planning, 72, Issue 4, 200209.

29. Pagney Bénito-Espinal, F. (2006). Les catastrophes naturelles : des entraves au développement dans le bassin caraïbe. In P. Joseph (dir.), La Caraïbe, données environnementales, Géode Caraïbe, Karthala, Paris, pp. 17-32.

30. Prax, A (2010). Inondations du Gard des 8 et 9 septembre 2002. Institut des Risques Majeurs, Risques Info, 24, 6-8.

31. Redon, M. (2006). Saint-Martin/Sint-Maarten, une petite île divisée pour de grands enjeux. Les Cahiers d'Outre-Mer, 234, 233-266.

32. Redon, M. (2007). Migrations et frontière : le cas de Saint-Martin. Études caribéennes, 8.

33. Sanguin, A.L. (1982). Saint-Martin, les mutations d'une île franco-néerlandaise des Antilles. Cahier d'outre-mer, 138, 123-140.

34. Servans, G., A. Naulin and L. Le Corre (2016). SaintMartin: Terre d'accueil et de contrastes. Insee Dossier Guadeloupe, 10, p. 24.

35. Veyret Y. (2017). Une catastrophe inévitable : SaintMartin (Antilles), une île à risques majeurs. Diplweb.com, p. 8. 